\title{
The Urgency of Prioritizing Indonesian Language for Efficiency of The Public Education Process to Against Endemic Threats
}

\author{
Nur Sitha Afrilia ${ }^{{ }^{*}}$, and M. Suryadi ${ }^{2}$ \\ ${ }^{1}$ Master of Literature Department of Indonesian literature, Faculty of Humanities, Diponegoro \\ University, Semarang - Indonesia \\ ${ }^{2}$ Master of Literature Department of Indonesian literature, Faculty of Humanities, Diponegoro \\ University, Semarang - Indonesia
}

\begin{abstract}
The threat of endemic that caused by the pandemic of global Covid-19 should be educated by a capable and well legitimized person. This is a manifestation of efforts to anticipate the fatal risks caused by the misleading information conveyed to the public. Indonesian language, as the primary medium that associates public communication, basically needs to optimize its function in order to be able to minimize the risk of misleading information. The researcher used qualitative methods by collecting information from the mass media, which used the diversity of medical terms, and words in regional languages that often triggers the ambiguity of meaning in the society. Therefore, it is necessary to have consistent collaboration between institutions to optimized the Indonesian language's function in the health education process. This optimization is also an embodiment of UU No.24 / 2009, which is the legal foundation for using Indonesian as the state's official language.
\end{abstract}

\section{Introduction}

In In early 2020, especially on March 11, 2020, the World Health Organization (WHO) declared the Corona outbreak a worldwide pandemic. The plague, which was detected in the Wuhan (China) at the end of 2019, quickly spread around the world, including Indonesia. Referring to the data updated by the Indonesian Ministry of Health, until May 30, 2021, there were 1,816,041 people tested and positive infected of Covid-19. Based on that total, 50,404 people were confirmed dead, and 1,663,998 people recovered. Meanwhile, on the global scale, according to data uploaded by WHO until May 30, 2021, Covid-19 has been spread in 223 countries, with the total number of exposed victims is up to $169,118,995$ people, and the number of confirmed has been dead amounting to 3,519,175.

Related to the information above, the researcher would limit the scope of the study about the relevance of the communication system to educate society about Covid-19. In this context, the communication system focuses on the urgency of using the Indonesian language as the primary language to expose the information regarding Covid-19. It causes based on

* Corresponding author: nursithaafrilia@,students.undip.ac.id 
data, $90 \%$ of the information in the health sector cannot be accounted for because it has unclear sources and spreads on massive through social media [1]. So, it is not surprising if there is so many misleading information on the society, and it has been a cause of chaos.

\section{Methodology}

In this paper, the researcher uses qualitative research methods as the primary method in the data assessment process. Research methodology is a method to explain the research problem [2] analytically. It may be described as a science of analysis of how research is done systematically. Whereas qualitative research methods are used to investigate, discover, describe, and explain the quality or features of social influences that cannot be explained, measured or described through a quantitative approach [3]. Besides it, in the qualitative method, the actual research is carried out irregularly, ambiguously, and tied to specific cases [4]. This, of course, reduces the set of rules and relies on informal procedures built by experiences in the field found by researchers.

Some articles were published on mass media, and opinions posted on media social have been an object for the researcher to observe the urgency of using the Indonesian language to handle the Covid-19 case. That is a background for the researcher use the qualitative research method because the observation is focused on the essential issue that exposes inside of article or opinion that posted on social media, which has been the cause of chaos in society.

\section{The Urgency of Prioritizing Indonesian Language to Against the Endemic Threats}

\subsection{The Difference of Pandemic and The Endemic}

Before describing the main topic, the researcher would explain the difference between a pandemic and an endemic. Pandemic is the plague were contagious everywhere and covering a wide geographic area [5]. Then, according to the same reference, an endemic means a disease that spreads in an area or a community group. One thing that should understand is that before the disease becomes a pandemic cause, it would be known as an epidemic that we could know as the infectious disease that spreads rapidly over a large area and causes many victims. Most of this kind is the disease which contagious and dangerous.

So, if we connect the definition above with the Covid-19 case, we can conclude that first, Covid-19 is an epidemic in Wuhan (China). Then, it was transformed by a pandemic because deployment was rapidly worldwide. Nowadays, it would be an endemic because there are no solutions to make this virus wholly lost. This opinion is not built by the perspective of the researcher. However, it was also built by some explanation from experts, and one of them was explained by Prof. Gusti Ngurah Mahardika (virologist from Udayana University, Indonesia). He was explained that the Covid-19 has similar characteristics to SARS and MERS. However, other features are not similar to them. These protein spikes play a role in pathogenicity. So, the epidemiological and pathological patterns of Covid-19 can resemble those of SARS and MERS. Alternatively, it may not resemble both. To be more accurate, we have to wait until the pandemic has passed. Even though it is just an impossible cause, the only real thing is that Covid-19 will be an endemic that exists in the world as a common disease. 


\subsection{The Urgency of Prioritizing Indonesian Language to Educate the Society}

CoComplicated is a word that is relevant for describing the condition nowadays. A lot of new words has been used to explain the Covid-19. However, most of them are words absorbed from medical words or foreign languages that were not common in society. Based on the perspective of the researcher, using a medical word is not a fault, because as part of a global society, we were also forced to be adaptive to everything. It also includes the way to speak and understand each other if we were using different terms of language. However, we should understand that the plurality of the word that we use can be interpreted on different meanings by the lay of society. Then, the impact of the different interpretations is hoax spread on massive. So, we can conclude that basically, many words that we use to educate society is the root of misleading information. It made an impact of unclear attitudes that should be taken by society to Before we discussed the urgency of prioritizing the Indonesian language, we should know that based on data were published as an article with the title "Analisis Perkembangan Kosakata Bahasa Indonesia pada Masa Pandemi Covid-19" by Sutarni and friends, the researcher found the fact that Indonesian language treasures have also grown during the pandemic. It is evidenced by the existence of various terms that are related to Covid-19, which have been absorbed in the national language. Sutarni and friends (2021) said that there were 9 words that were overused in the early pandemic, but nowadays, those words have been absorbed in Indonesian, like in the table below [6].

Table 1. Adsorbed Word of Covid-19 Term in Indonesian.

\begin{tabular}{|c|c|c|}
\hline No. & English (International Term) & Indonesian \\
\hline 1 & Social Distancing & Pembatasan Sosial \\
\hline 2 & Lockdown & Karantina Wilayah \\
\hline 3 & New Normal & Kenormalan Baru \\
\hline 4 & Herd Immunity & Kekebalan Kelompok \\
\hline 5 & Rapid Test & Tes Cepat \\
\hline 6 & Swab Test & Tes Usap \\
\hline 7 & Physical Distancing & Pembatasan Fisik \\
\hline 8 & Imported Case & Kasus Impor \\
\hline 9 & Suspect & Teduga \\
\hline
\end{tabular}

Beside of that data from an article entitled "Sumbangan Bahasa Indonesia terhadap Pengendalian Covid-19" has been concluded that Indonesian language took a part to contribute in the form of words, phrases, and sentences [7]. It means, Indonesian language has been adapted as the golden key for educate the society about the Covid-19. The meaning of golden key in this case is Indonesian language could be a main media to use by society, include the government, mass media and every person who live in here (Indonesia). It caused of based on amount of traditional languages that reaches to 718 which exist in Indonesia, we should to realize that each community would has a different interpretation about some words. It means, if we do not have a main media to communicate for build a same perception, we will face a lot of potential disinformation which lead to chaos. Not only that, if we do not care with the main media, we could be easy to be tricked by person who want to increase the panic attack in the society. So, the researcher was concluded that basically we should realize to prioritize of Indonesian language, in order to ensure that we are ready for facing the endemic threats.

Relevant to the explanation above which important to note is, according to data from Indonesia Investment, Indonesian people's understanding of English is ranked 32 out of 72 countries. In fact, in the early days of determining the status of the Covid-19 pandemic or 
around mid-2020, the majority of academic journals or scientific articles published by western countries were in English. It means, at that time, people who were ignorant of foreign language skills and experts who did not care about the urgency of using the simple Indonesian language to communicate about the dangers of Covid-19, was taking a part in the process of accelerating the occurrence of the endemic. This is due to the lack of public understanding about the credible information and the habit of talkative in disseminating information that has not been validated for accuracy. Therefore, it is not surprising that there are many hoaxes that are triggered by the speed in sharing information that is not matched by the capture of the essence of information that is not presented in Indonesian.

Related with that statement, we can reflect to the chaos that made by Lois Owen at the end of June (2021). She used Indonesian language to made a lot of statuses on her media social. But, the problem is, most of her statement was creating the hoaxes about the Covid19. Her statement that so dangerous is like the picture below.

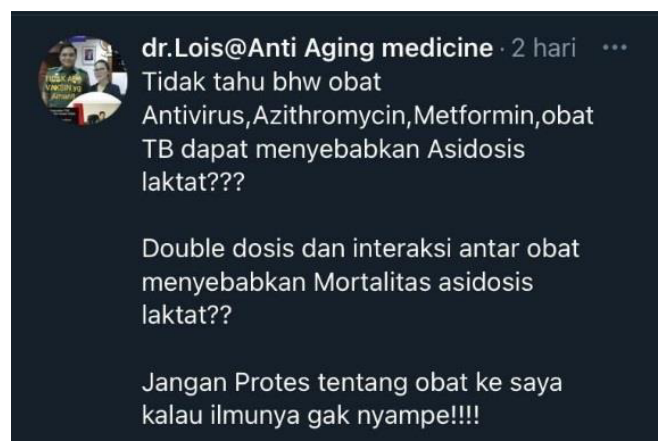

Fig. 1. Screenshot of Lois Owen's Statement on her Twitter.

(Source: https://www.idntimes.com/news/indonesia/irfanfathurohman/) [8]

Referring to her statement, we can conclude that using the Indonesian language did not mean using Indonesian words. We need the wisdom to write any opinions and commit to making a clear statement for society. A statement written without wisdom and the explicit goal has a considerable potency to be a roar of chaos like Lois did.

Contrary to what Louis did, Dr Faheem as a doctor who is competent in education for society about Covid-19, precisely chose to use the Indonesian language for his process by spreading information about how to fight the Covid-19, including the urgency of the vaccine. Dr Faheem is a doctor from America, but he has a significant commitment to educating Indonesian society against the Covid-19. It causes of based on his perspective, Indonesia on the dire situation to face that virus. He told the audience at the Symposium of Covid-19, which hold by Humanity First Indonesia on June 17, 2021, that it was not his first time to educate global society against the pandemic. He ever used his Twitter to help Indian people when they were in crisis (pandemic) and also uploaded the tweets in Spanish for South American people, like Peru, Brazil, Ecuador, Argentina, because most of them were not aware of how to severe the pandemic there. Related to his statement, we can conclude that, in fact, the national language which exists in each country is the main media that could to used for the education process, especially for spreading information related to issues that urgent like how to against the Covid-19 on nowadays.

Based on the information above, it is fitting for all parties who are capable of collaborating with each other for strengthening their commitment to prioritizing the Indonesian language in the realm of public education, related to the dissemination of information about Covid-19. Dissemination of information in Indonesian in this context is 
not only fixated on the use of good and correct grammar according to PUEBI (Pedoman Umum Ejaan Bahasa Indonesia) rules but, there is also an agreement in mentioning medical terms, so the information can be easy to understand by all levels of society. One thing that can't be denied is that the perception of the understanding of a word's meaning by society is not necessarily the same. So, if it just mentions an unpopular term, then it is not surprising that it will lead to confusion in society and also increase the potential to ignore all appeals. Not only it, using an Indonesian word or term without wisdom has the same meaning to increase the hoaxes and create more chaos.

\section{Conclusion}

In the end, the Covid-19 virus, which was initially an epidemic in one of the regions, will now be transformed into an endemic and humans are required to be more prepared and alert to deal with changes in living systems caused by this endemic. However, if this readiness and readiness are not immediately established from now on, then it is not impossible that new problems triggered by misinformation regarding Covid-19 will emerge. Therefore, the researcher hopes that all parties will realize the importance of prioritizing Indonesian in the public sphere, especially in critical times like this. Given, Indonesia is a large nation and a country that has a plurality of regional languages. If there is no strengthening of commitment to prioritizing Indonesian and agreeing on uniformity of meaning in each labelling of terms, then it is not impossible if, in the future, people will stutter in facing the challenges of a new life with this endemic.

More than it, prioritizing the use of the Indonesian language means also carrying out the mandate contained in Law No.24 of 2009 concerning the obligation to use the Indonesian language as the main medium for delivering public information.

\section{References}

1. C. Judhita, Perilaku Masyarakat terkait Penyebaran Hoax Covid-19, Pekommas, 5(2), 105-116, (BBPSDMP Kominfo Makasar, 2020)

2. C. R. Kothari, Research Methodology: Methods and Techniques 2nd revised edition, (New Age International (P) Limited, Publishers New Delhi, 2004)

3. Saryono, Metode Penelitian Kualitatif, (PT. Alfabeta Bandung, 2010)

4. Neuman, W. Laurence, Metodologi Penelitian Sosial: Pendekatan Kualitatif dan Kuantitatif, (Indeks Jakarta, 2017)

5. Kamus Besar Bahasa Indonesia, (2021), Retrieved from https://kbbi.kemdikbud.go.id

6. Sutarni, Sutikno, Wariyati, Analisis Perkembangan Kosakata Bahasa Indonesia pada Masa Pandemi Covid-19, Terapan Informatika Nusantara, 1(10), 499:502, (Forum Kerja Sama Pendidikan Tinggi (FKPT) Medan, 2021)

7. Pranowo, (2020), Sumbangan Bahasa Indonesia terhadap Pengendalian Covid-19, Retrieved from http:/ejournal.stkipsiliwangi.ac.id/index.php/semantik/article/view/1738

8. I. Fathurohman, (2021), Polri: Dokter Lois Owien Ditangkap karena Menyebarkan Hoaks Covid-19, Retrieved from https://www.idntimes.com/news/indonesia/irfanfathurohman/polri-dokter-lois-owienditangkap-karena-menyebarkan-hoaks-covid/2

9. F. Alfarisy, Kajian Budaya: Kebijakan Berbahasa di Tengah Pandemi Covid-19, Anuva, 4(3), 343-353, (Universitas Diponegoro Semarang, 2020) 
10. D. Septina, (2021), Ini Alasan Twitter Dr Faheem Younus Aktif Edukasi Soal Covid-19 Pakai Bahasa Indonesia, Retrieved from https://www.kompas.tv/article/193892/inialasan-twitter-dr-faheem-younus-aktif-edukasi-soal-covid-19-pakai-bahasa-indonesia

11. G. R. Somarni, Memahami Metode Kualitatif, Makara, 2(9), 57-65 (2005) 